\title{
Investigations of potential microbial methanogenic and carbon monoxide utilization pathways in ultra-basic reducing springs associated with present-day continental serpentinization: the Tablelands, NL, CAN
}

\author{
Penny L. Morrill ${ }^{1}$, William J. Brazelton ${ }^{2}$, Lukas Kohl' ${ }^{1}$, Amanda Rietze ${ }^{1}$, Sarah M. Miles ${ }^{1}$, \\ Heidi Kavanagh ${ }^{1}$, Matthew O. Schrenk ${ }^{3}$, Susan E. Ziegler ${ }^{1}$ and Susan Q. Lang ${ }^{4 t}$ \\ Department of Earth Sciences, Memorial University, St. John's, NL, Canada \\ ${ }^{2}$ Department of Biology, University of Utah, Salt Lake City, UT, USA \\ ${ }^{3}$ Department of Geological Sciences, Michigan State University, East Lansing, MI, USA \\ ${ }^{4}$ Department of Earth Sciences, ETH-Zürich, Zürich, Switzerland
}

\section{Edited by:}

Dawn Cardace, University of Rhode Island, USA

Reviewed by:

Ronald Oremland, United States

Geological Survey, USA

D'Arcy Renee Meyer-Dombard,

University of Illinois at Chicago, USA

*Correspondence:

Penny L. Morrill, Department of Earth Sciences, Memorial University of Newfoundland, Alexander Murray Building, 300 Prince Philip Drive, St. John's, NL A1B 3X5, Canada e-mail:pmorrill@mun.ca

${ }^{\dagger}$ Present address:

Susan Q. Lang, Department of Earth and Ocean Sciences, University of South Carolina, Columbia, SC, USA
Ultra-basic reducing springs at continental sites of serpentinization act as portals into the biogeochemistry of a subsurface environment with $\mathrm{H}_{2}$ and $\mathrm{CH}_{4}$ present. Very little, however, is known about the carbon substrate utilization, energy sources, and metabolic pathways of the microorganisms that live in this ultra-basic environment. The potential for microbial methanogenesis with bicarbonate, formate, acetate, and propionate precursors and carbon monoxide (CO) utilization pathways were tested in laboratory experiments by adding substrates to water and sediment from the Tablelands, NL, CAD, a site of present-day continental serpentinization. Microbial methanogenesis was not observed after bicarbonate, formate, acetate, or propionate addition. CO was consumed in the live experiments but not in the killed controls and the residual $\mathrm{CO}$ in the live experiments became enriched in ${ }^{13} \mathrm{C}$. The average isotopic enrichment factor resulting from this microbial utilization of $\mathrm{CO}$ was estimated to be $11.2 \pm 0.2 \%$. Phospholipid fatty acid concentrations and $\delta^{13} \mathrm{C}$ values suggest limited incorporation of carbon from $\mathrm{CO}$ into microbial lipids. This indicates that in our experiments, CO was used primarily as an energy source, but not for biomass growth. Environmental DNA sequencing of spring fluids collected at the same time as the addition experiments yielded a large proportion of Hydrogenophaga-related sequences, which is consistent with previous metagenomic data indicating the potential for these taxa to utilize $\mathrm{CO}$.

Keywords: serpentinization, Tablelands, carbon monoxide, methanogenisis, phospholipid fatty acids

\section{INTRODUCTION}

The geochemical composition of spring fluids can provide insight into serpentinization driven subsurface processes, but these indicators are often overlaid by microbial biogeochemical transformations, which remain poorly understood in these extreme ecosystems. Geochemically distinct fluids associated with serpentinization result from subsurface water-rock reactions whereby groundwater or ocean water reacts with ultramafic rock (peridotite), producing serpentine minerals, $\mathrm{H}_{2}$ gas, and hydroxide ions (Barnes et al., 1967; Sleep et al., 2004, 2011). The resulting fluids create an ultra-basic and reducing subsurface habitat. Present-day serpentinization occurs in slowly spreading marine ridges such as Lost City (Kelley et al., 2005), or at continental sites such as the Zambales ophiolite, Philippines (Abrajano et al., 1990); Semail ophiolite, Oman (Neal and Stanger, 1983; Fritz et al., 1992); Tekirova ophiolites, Turkey (Hosgormez, 2007); Cabeço de Vide Aquifer (CVA), Portugal (Marques et al., 2008); The Cedars, United States (Barnes et al., 1967); Del Puerto Ophiolite, California Coast Range, United States (Blank et al.,
2009) and the Tablelands, Canada (Szponar et al., 2013). The continental sites share similar geochemical characteristics such as high $\mathrm{pH}$, low $\mathrm{E}_{\mathrm{h}}$, scarce electron acceptors, and limited dissolved inorganic carbon for autotrophic growth, which is considered extreme for most microbial life as we know it. However, geochemical measurements (Morrill et al., 2013) and genomics (Blank et al., 2009; Brazelton et al., 2012; Suzuki et al., 2013; Tiago and Verissimo, 2013) have demonstrated that life may exist in these environments. Additionally, Suzuki et al. (2014) have cultured organisms at high $\mathrm{pH}$ that correspond to highly abundant organisms in these serpentinizing environments, which are also the same taxa (Serpentinomas/Hydrogenophaga) observed at the Tablelands (Suzuki et al., 2014).

Dissolved or bubbling methane gas is common in fluids associated with sites of present-day serpentinization. The geologic setting and the water-rock reactions that occur at sites of presentday serpentinization in continental ophiolites create conditions amenable for the production of microbial, thermogenic, and/or abiogenic methane (Szponar et al., 2013). Geochemical indicators 
at most sites of serpentinization suggest that the methane produced is primarily non-microbial in origin (Neal and Stanger, 1983; Abrajano et al., 1990; Fritz et al., 1992; Hosgormez, 2007; Proskurowski et al., 2008; Szponar et al., 2013). However, there is still a potential for microbial production of methane at other sites of serpentinization. Methanogenic archaea have been noted at marine sites of serpentinization (Brazelton et al., 2006; Perner et al., 2007; Brazelton and Baross, 2010). At continental sites of serpentinization, methanogens were detected in the Del Puerto Ophiolite in the California Coast Range (Blank et al., 2009) and The Cedars (Suzuki et al., 2013), but the abundances, distributions, and diversity of methanogens have not been explored in these systems. In addition to genomic data, geochemical data from The Cedars did not preclude microbial methane production (Morrill et al., 2013). In previous studies at the Tablelands, sequences related to methanogens were extremely rare in the metagenomic dataset, and no genes indicative of methanogenesis were identified (Brazelton et al., 2012).

Microbial methane can be formed autotrophically (i.e., carbonate reduction, Equation 1), or heterotrophically (e.g., with organic acid substrates, Equation $2 \mathrm{a}$ and $2 \mathrm{~b}$ ).

$$
\begin{gathered}
\mathrm{CO}_{2}+4 \mathrm{H}_{2} \rightarrow \mathrm{CH}_{4}+2 \mathrm{H}_{2} \mathrm{O} \\
3 \mathrm{H}_{2}+\mathrm{HCOO}^{-}+\mathrm{H}^{+} \rightarrow \mathrm{CH}_{4}+2 \mathrm{H}_{2} \mathrm{O} \\
\mathrm{CH}_{3} \mathrm{COO}^{-}+\mathrm{H}_{2} \mathrm{O} \rightarrow \mathrm{CH}_{4}+\mathrm{CO}_{3}^{2-}+\mathrm{H}^{+}
\end{gathered}
$$

Organic acids, i.e., acetate and formate, are enriched at the Lost City hydrothermal field, a serpentinizing system (Lang et al., 2010). These organic acids may be present at sites of continental serpentinization and may be the carbon source for heterotrophic methanogenesis. $\mathrm{CO}_{2}$ for microbial methanogenesis via carbonate reduction (Equation 1) is potentially limited at high $\mathrm{pH}$ values because at $\mathrm{pH}$ values greater than 11 , the dominant species of dissolved $\mathrm{CO}_{2}$ is not the biologically available bicarbonate $\left(\mathrm{HCO}_{3}^{-}\right)$, but instead the carbonate ion $\left(\mathrm{CO}_{3}^{2-}\right)$ that precipitates with the ample $\mathrm{Ca}^{2+}$ in serpentinizing systems. A recent study by Suzuki et al. (2014) found that Serpentinomonas, an organism adapted to the high $\mathrm{pH}$ and high $\mathrm{Ca}^{2+}$ concentrations characteristic of sites of serpentinization, used calcium carbonate for carbon fixation. These results suggest there maybe unknown pathways for $\mathrm{CO}_{2}$ reduction in high $\mathrm{pH}$ systems such as sites of serpentinization.

Microorganisms commonly found at sites of serpentinization may be able to use $\mathrm{CO}$ as the electron donor and carbon source. This pathway is catalyzed by the enzyme carbon monoxide dehydrogenase (CODH) (King and Weber, 2007), and gene sequences encoding for $\mathrm{CODH}$ were present in high abundance in the metagenome of the WHC2b spring (Brazelton et al., 2012). The $\mathrm{CODH}$ enzyme (A) is used to convert the available CO from the environment to $\mathrm{CO}_{2}$ (Equation 3), which is then used in further metabolic processes.

$$
\mathrm{CO}+\mathrm{H}_{2} \mathrm{O}+\mathrm{A} \rightarrow \mathrm{CO}_{2}+\mathrm{AH}_{2}
$$

There is evidence of microorganisms at the Tablelands site with phylogentic affinity to the microorganism Hydrogenophaga pseudoflava, an autotrophic member of the Comamonadaceae family within the Betaproteobacteria (Brazelton et al., 2012). These microorganisms are facultative anaerobes that can grow autotrophically on $\mathrm{H}_{2}$ or fix $\mathrm{CO}$ when organic carbon is unavailable (Willems et al., 1989). Hydrogenophaga-related organisms and other organisms of the Comamonadaceae family have been detected at many sites of serpentinization where ultra-basic fluid mixes with either shallow groundwater or overland flow in pools of water (Schrenk et al., 2013; Suzuki et al., 2014).

An environment with high redox gradients exists at the surface where ultra-basic reducing springs associated with subsurface serpentinization discharge into pools of fluids that are open to inputs from shallow groundwater, overland flow, precipitation and the atmosphere. The microbial composition of these pools may be different from those of the subsurface. These mixing pools act as portals between the surface and the subsurface. The ultra-basic, reducing pool in the Tablelands, Gros Morne National Park, NL, $\mathrm{CAN}$, is one location where carbon substrate utilization can be studied in one of the ultra-basic reducing portals between the serpentinizing subsurface and the oxic surface environments where mixing has been constrained (Brazelton et al., 2013; Szponar et al., 2013).

The Tablelands, also known as the Table Mountain massif, is one of four Ordovician ophiolites that make up the Bay of Islands Complex (BOIC) which runs along the west coast of Newfoundland, Canada in the Humber Arm Allochthon tectonic zone (Suhr and Cawood, 1993). The Humber Arm Allochthon is a mixture of deep sea sediments, mafic crustal material and mantle peridotites from the ancient seafloor that was assembled and obducted onto the eastern edge of the North American Craton about $500 \mathrm{Ma}$ ago as the Iapetus Ocean was closing during the Taconian orogeny (Suhr, 1992; Suhr and Cawood, 1993). The mantle peridotite located at the Tablelands is classified as harzburgite and lherzolite, which have varying proportions of the ultramafic minerals olivine, orthopyroxene and clinopyroxene (Suhr, 1992). Recent serpentinization of the ultramafic body, which was most likely rejuvenated after the last glaciation $(\sim 12,000$ years ago $)$ when isostatic rebound created new cracks and fissures that exposed unreacted ultramafic rocks to groundwater, produced highly reducing $(\sim-600 \mathrm{mV})$ and ultrabasic $(\mathrm{pH}>11)$ waters rich in hydrogen gas, methane and other low molecular weight hydrocarbons $\left(C_{2}-C_{6}\right)$ (Szponar et al., 2013). These fluids have been identified discharging from multiple active springs in pools of water (e.g., WHC1 and WHC2) surrounded by travertine deposits at the Tablelands providing evidence of present-day serpentinization.

The first objective of this study was to characterize the geochemistry and metabolic diversity of microorganisms within the mixed WHC2 pool and the ultra-basic water that discharges into the pool. The second objective was to determine the potential for microbial methanogenesis using inorganic carbon and organic acid substrates, and for microbial CO utilization using stable isotope probing and isotopic fractionation with non-labeled substrates. The results from this study provide empirical evidence in support of microbial CO utilization in agreement with earlier metagenomic studies. However, the results from this study do not provide evidence for microbial methanogenesis using the organic 
acids detected at sites of serpentinization or inorganic carbon within serpentinizing settings.

\section{METHODS}

\section{SITE DESCRIPTION AND SAMPLING PROCEDURE}

Water and sediments were sampled from pool WHC2 (N $\left.49^{\circ} 27^{\prime} 58.7^{\prime \prime} \mathrm{W} 057^{\circ} 57^{\prime} 29.2^{\prime \prime}\right)$. This pool of water was approximately $130 \mathrm{~cm}$ wide and $40 \mathrm{~cm}$ deep surrounded by travertine deposits and was exposed to the atmosphere at the surface. Within this pool two springs located at the bottom of the pool have been identified by low $\mathrm{E}_{\mathrm{h}}$ values and are labeled $\mathrm{A}$ and $\mathrm{B}$ (i.e., WHC2A and WHC2B) (Figure 1). A site labeled C (WHC2C) represented a mixing site where overland water from a tributary of the brook was flowing into the highly reducing pool of water. Previous work by Szponar et al. (2013) and Brazelton et al. (2012) describe the various kinds of contamination at this site and demonstrated geochemically that the sources of fluid at the bottom of the WHC2 pool are distinct from any surface sources. In June, 2011, water and sediments were sampled from WHC2A for the bicarbonate and organic acid addition experiments. In October, 2012, an artificial dam was created diverting the overland flow from WHC2C, and the WHC2 pool was emptied. Ultra-basic reducing groundwater springs recharged the pool. The pool was emptied again multiple times before pool sediments and recharging waters at $\mathrm{WHC} 2 \mathrm{~A}$ were sampled for the $\mathrm{CO}$ addition experiments. Geochemical field parameters $\left(\mathrm{pH}, \mathrm{E}_{\mathrm{h}}\right.$, sulfate, nitrate, phosphate, total inorganic carbon (TIC), $\delta^{13} \mathrm{C}_{\mathrm{TIC}}$, dissolved organic carbon (DOC), $\delta^{13} \mathrm{C}_{\mathrm{DOC}}, \mathrm{CH}_{4}, \delta^{13} \mathrm{C}_{\mathrm{CH} 4}$ ) were sampled for in 2011 and 2012.

Samples for total inorganic carbon (TIC) and dissolved organic carbon (DOC) were collected for both concentration and stable carbon isotope $\left(\delta^{13} \mathrm{C}\right)$ values in pre-combusted $40 \mathrm{~mL}$ amber vials spiked with mercuric chloride $\left(\mathrm{HgCl}_{2}\right)$ and phosphoric acid $\left(\mathrm{H}_{3} \mathrm{PO}_{4}\right)$ respectively. Samples for DOC were filtered through a $0.7 \mu \mathrm{m}$ pre-combusted glass microfiber filter.

Dissolved $\mathrm{CH}_{4}, \mathrm{H}_{2}$, and $\mathrm{CO}$ were sampled using a modified syringe gas phase equilibration technique by McAuliffe (1971) and Rudd et al. (1974). Twenty milliliters of fluid was withdrawn with a $60 \mathrm{~mL}$ sterile syringe and shaken vigorously for $5 \mathrm{~min}$ with an equal volume of helium (He). This allowed for partitioning of the dissolved gas in the sample water into to the gas phase. The entire gas phase of 2 syringes $(40 \mathrm{~mL})$ was injected into a $30 \mathrm{~mL}$ serum vial, prefilled with degassed water and sealed with blue butyl stoppers. The dissolved gases in He displaced the water in the serum vial. Samples were fixed with $5 \mu \mathrm{L}$-saturated solution of $\mathrm{HgCl}_{2}$ to ensure there was no microbial growth in bottles. Dissolved $\mathrm{CH}_{4}$ was sampled for $\delta^{13} \mathrm{C}$ analysis by collecting $50 \mathrm{~mL}$ of fluid using a $60 \mathrm{~mL}$ sterile syringe and injecting samples into a pre-evacuated $125 \mathrm{~mL}$ serum vial fixed with $\mathrm{HgCl}_{2}$ and sealed with blue butyl stoppers.

Fluid was filtered through a sterile $0.22 \mu \mathrm{m}$ (25 mm ID) MCE membrane filter and collected in clean $15 \mathrm{~mL}$ test tubes with a sterile $60 \mathrm{~mL}$ syringe for the analysis of sodium, potassium, sulfate, nitrate, and phosphate. Samples were kept frozen and dark until analysis. Thirty $\mathrm{mls}$ of water were collected in $50 \mathrm{ml}$ falcon tubes for formate, acetate concentrations. These samples were kept frozen and dark until analysis.

Formate and acetate concentrations were measured at the Swiss Federal Institute of Technology (ETH) in Zurich, Switzerland on a Surveyor high performance liquid chromatograph (HPLC) with a P1000 pump and a PDA Plus 5 Diode Array Detector with a $50 \mathrm{~mm}$ cell path following the method of Albert and Martens (1997) with minor modifications. Adipic acid $(20 \mathrm{nmol})$ was used as an internal standard and was injected into the sample before derivitization. Following derivitization an aliquot of sample $(0.4 \mathrm{~mL})$ was injected into a $1.5 \mathrm{~cm}$ Prevail
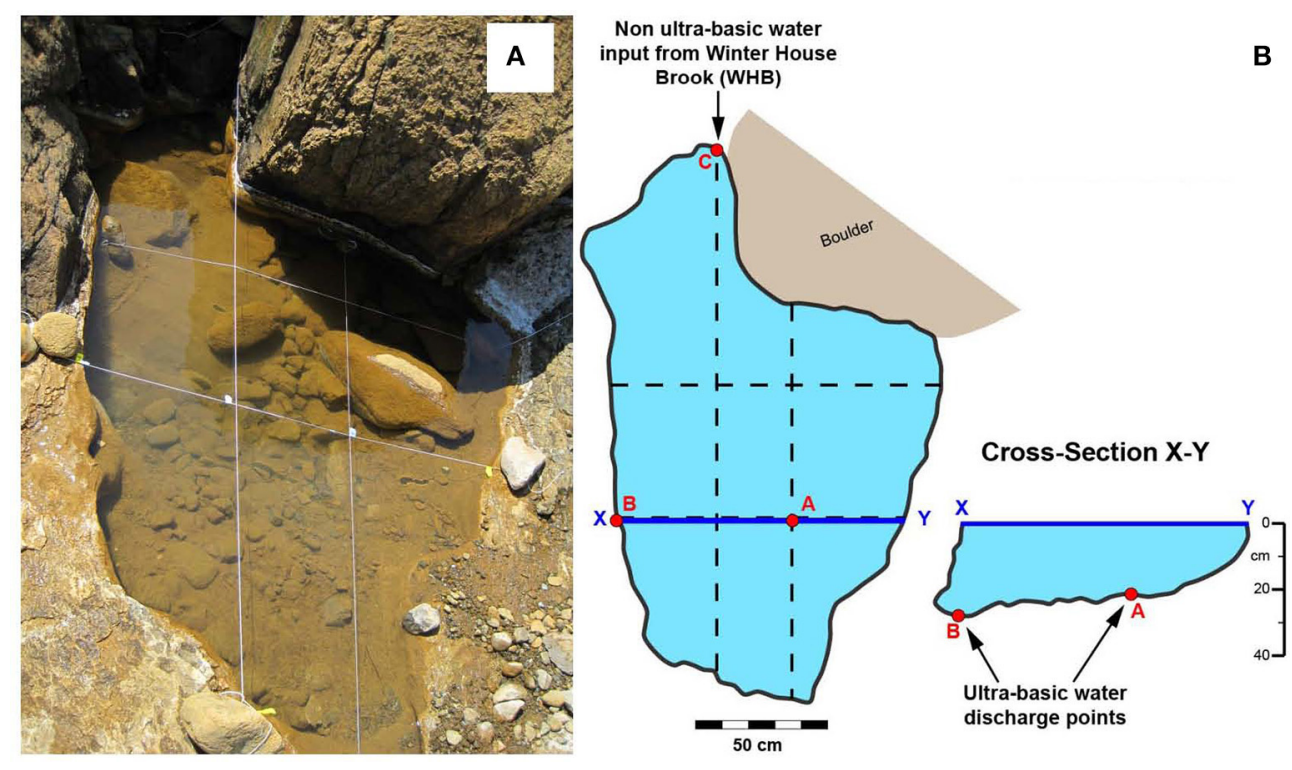

FIGURE 1 | (A) Photograph of WHC2 ultra-basic pool. (B) Schematic planar and cross sectional sketches depicting the various water inputs into the WHC2 pool- $\mathrm{A}$ and $\mathrm{B}$ are locations of ultra-basic reducing water discharging into the bottom of the pool, $\mathrm{C}$ is the location of overland flow that trickles into WHC2. 
Organic Acid C18 guard column $(4.6 \times 250 \mathrm{~mm}$ ID, $5 \mu \mathrm{m}$ film thickness, Grace Davison Discovery Sciences) using an autosampler equipped with a $1 \mathrm{~mL}$ syringe. The mobile phase in the column was varying gradients of two solutions. Solvent A was 2.5\% n-butanol, $50 \mathrm{mM}$ sodium acetate, $2 \mathrm{mM}$ tetrabutylammonium hydroxide, $50 \mathrm{mM}$ tetradecyltrimethylammonium bromide with phosphoric acid which was used to adjust the $\mathrm{pH}$ to 4.5 . Solvent B was pure methanol. The gradient program was as follows: 75:25 (A:B) for $23 \mathrm{~min}$, then transitioned to a 50:50 mixture over $5 \mathrm{~min}$, held at 50:50 for $5 \mathrm{~min}$, then returned to a 75:25 mixture over $5 \mathrm{~min}$ and equilibrated at 75:25 for $5 \mathrm{~min}$. Peaks were detected at $400 \mathrm{~nm}$. The analytical error of individual measurements for acetate and formate was \pm 0.012 and $\pm 0.06 \mathrm{mg} \mathrm{C} / \mathrm{L}$, respectively. The reproducibility of duplicate analysis ranged from 4 to $48 \%$ RSD.

\section{ENVIRONMENTAL DNA SEQUENCING}

Sequences of bacterial 16S rRNA genes from WHC2 pool samples collected in 2010 and 2011 have been previously published (Brazelton et al., 2013). For this study, additional environmental $16 \mathrm{~S}$ rRNA gene sequences were collected from the WHC2 pool before and after it was emptied several times and allowed to refill. Filtering of the fluids and DNA extractions of the filters were conducted as described previously (Brazelton et al., 2013) and briefly summarized here. Sterivex filters were stored on wet ice in the field, frozen in liquid nitrogen as soon as possible, transported on dry ice, and stored at $-80^{\circ} \mathrm{C}$. DNA extractions were performed by lysis via freeze/thaw cycles and lysozyme/Proteinase $\mathrm{K}$ treatment and purified with phenol-chloroform extractions, precipitation in ethanol, and further purification with QiaAmp (Qiagen, Hilden, Germany) columns according to the manufacturer's instructions for purification of genomic DNA. Purified DNA was submitted to the Josephine Bay Paul Center, Marine Biological Laboratory (MBL) at Woods Hole for amplicon sequencing of the bacterial 16S rRNA gene via an Illumina MiSeq platform. Amplification and sequencing protocols developed at the MBL and an updated version of the protocol is available in Nelson et al. (2014). Qualityfiltering of the sequences was conducted via the VAMPS pipeline (Huse et al., 2014).

Previously published environmental 16S rRNA sequences derived from three WHC2 samples collected in 2010 and 2011 (Brazelton et al., 2013) were generated at the DOE Joint Genome Institute with a MiSeq sequencing platform according to well-established protocols (Caporaso et al., 2012). The previously published JGI sequences and new sequences reported here from the MBL were generated with similar but nonidentical methodologies. Therefore, we also re-submitted two of the 2010-2011 samples for which sequences were previously published (WHC2B-2010 and WHC2C-2011) to the MBL for sequencing with the updated MiSeq protocol to provide a more direct comparison with the 2012 samples.

Environmental 16S rRNA sequences were also collected from sediments at the bottom of the pool that were sampled in 2010 and 2011. These sediments were collected from the same location but at a different time than the sediments collected for the 2012 experiments described below. Sediments were sampled by suction with a sterile $60 \mathrm{~mL}$ disposable syringe. Sediments were allowed to settle in the syringe for several minutes, and the overlying fluid was expelled. Additional sediment was then sampled by suction into the same syringe, and the settling and fluid expulsion was repeated until the syringe was approximately halffull of sediment. The differentiation between spring- and water column-derived microbes using this method at this site has been previous published by Brazelton et al. (2013). Sediment samples were contributed to the Earth Microbiome Project (EMP; http:// www.earthmicrobiome.org), which handled the DNA extraction via the MoBio PowerSoil kit and amplicon sequencing via the Illumina MiSeq platform as described by Caporaso et al. (2012).

Taxonomic classification of all sequences was performed using the SILVA reference alignment (SSURefv115) and taxonomy outline (Pruesse et al., 2007) using the mothur software platform (v.1.32.1) (Schloss et al., 2009). Figure 2 and supplementary material were generated in $\mathrm{R}$ (v.3.1.0) with the phyloseq package (v.1.9.4) (McMurdie and Holmes, 2013) using the taxonomic counts generated by mothur. Family-level classifications are shown in Figure 2 and supplementary material because the most common sequences could not be classified at lower taxonomic levels. MBL-generated sequences are freely available at the VAMPS database (http://vamps.mbl.edu) under the project code DCO_BRZ. All EMP-generated sequences are available via their database at http://www.microbio.me/emp under EMP Project ID 713: Serpentinite Seeps.

\section{EXPERIMENTAL SAMPLING AND APPROACH Methanogenesis experiments with organic acids and bicarbonate substrates}

Sediment and water from WHC2A, the most ultra-basic reducing location in WHC2, were sampled anaerobically for the microbial carbonate reduction and organic acid fermentative methanogenesis studies (July, 2011). In the field, capped $12 \mathrm{ml}$ exetainers (Labco Ltd., UK), which were prefilled with $\mathrm{N}_{2}$ gas, were lowered to the bottom of the WHC2 pool, the cap with a rubber septum was removed and ultra-basic reducing water displaced most of the $\mathrm{N}_{2}$ gas. The carbonate was of particular interest because, in a previous study, data indicated higher microbial concentrations within the carbonate sediment compared to the water itself (Szponar, 2012). While the exetainer was still under the water, $\sim 2 \mathrm{ml}$ carbonate sediment slurry was scooped into the exetainer. The exetainer was recapped underwater and stored upside down in the dark and transported to Memorial University. In the laboratory, $2 \mathrm{ml}$ of water in each exetainer were displaced with an $\mathrm{H}_{2}$-rich headspace through the rubber septa. The exetainers were stored upside-down during the incubations.

To test for the potential of autotrophic or organic acid fermentative methanogenesis ${ }^{13} \mathrm{C}$ labeled bicarbonate (autotrophic methanogenesis) or ${ }^{13} \mathrm{C}$ labeled organic acid (fermentative methanogenesis) were added to the exetainers and the $\delta^{13} \mathrm{C}$ in $\mathrm{CH}_{4}$ and $\mathrm{CO}_{2}$ in the headspace was analyzed after incubation. These experiments were conducted with five labeled substrates, bicarbonate, formate, two isotopomers of positionspecific labeled acetate $\left({ }^{13} \mathrm{CH}_{3} \mathrm{COO}^{-}\right.$and $\left.\mathrm{CH}_{3}^{13} \mathrm{COO}^{-}\right)$, and uniformly labeled propionate. For each incubation with a ${ }^{13} \mathrm{C}$ labeled substrate, two controls were conducted, either by adding the nonlabeled substrate (live non-labeled control), or by adding labeled 


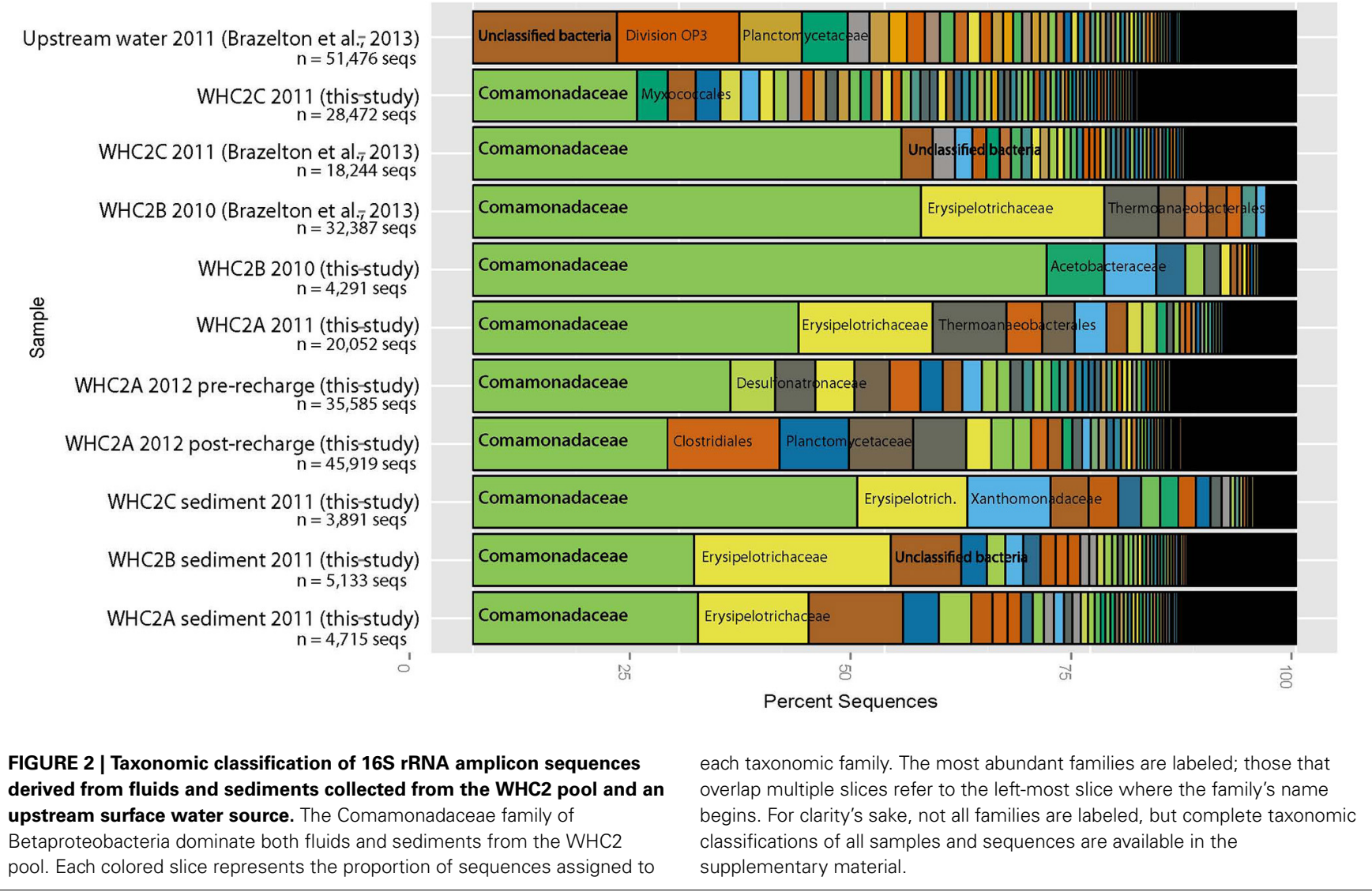

substrate but inhibiting microbial activity by acidifying the fluid with $0.05 \mathrm{~mL}$ concentrated $\mathrm{HCl}$ to $\mathrm{pH} \sim 1$ (killed ${ }^{13} \mathrm{C}$-labeled control). $0.3 \mathrm{~mL}$ of a $0.1 \mathrm{M}$ solution of the unlabeled substrate were added to each exetainer. $0.1 \mathrm{~mL}$ of a $0.001 \mathrm{M}$ solution of the $99 \%{ }^{13} \mathrm{C}$ labeled substrate (Cambridge Isotope Laboratories, Cambridge, MA) were added to the live ${ }^{13} \mathrm{C}$-labeled and killed ${ }^{13} \mathrm{C}$-labeled treatments. After the substrate additions, the naturally occurring organic acids and inorganic carbon ranged from 1 to $4 \%$ of the total substrate concentration. After four months of incubation, stable carbon isotope values of $\mathrm{CH}_{4}$ and $\mathrm{CO}_{2}$ were measured.

\section{CO utilization experiments}

Water and sediment samples were collected at the Tablelands from WHC2A in October, 2012. Liquid and sediment samples were collected by completely submerging a $1 \mathrm{~L}$ capped bottle under the water surface. At the bottom of the pool, the bottle cap was removed, and water and sediment were collected. In the laboratory, nine $\mathrm{CO}$ utilization experimental bottles were prepared (three live ${ }^{13} \mathrm{C}$-labeled substrates, three live non-labeled controls, and three killed non-labeled controls).

The CO utilization experiments were performed aerobically. Equal amounts of sediment $(7 \mathrm{~g})$ and ultra-basic water $(70 \mathrm{~mL})$ were added to each bottle. All nine bottles received $10 \mathrm{~mL}$ of mineral medium for chemolithotrophic growth (DSMZ medium 81), and were sealed with blue butyl septa and aluminum crimp seals. Contamination of volatile organic compounds present in the blue butyl stoppers was avoided by conditioning (i.e., boiling for $1 \mathrm{~h}$ in $0.1 \mathrm{~N} \mathrm{NaOH}$, followed by immersion in distilled water for $8 \mathrm{~h}$, Oremland et al., 1987). All three killed controls received $1.4 \mathrm{~mL}$ of concentrated hydrochloric acid $(\mathrm{HCl})$ which decreased the $\mathrm{pH}$ to $\leq 1$. Two hundred microliters of non-labeled $\mathrm{CO}$ (i.e., $\mathrm{CO}$ with a natural abundance of ${ }^{13} \mathrm{C} /{ }^{12} \mathrm{C}, \delta^{13} \mathrm{C}_{\mathrm{CO}}=-44.4 \%$ ) were added to all bottles. Ten microliters ${ }^{13} \mathrm{C}$-labeled CO $\left(99 \%{ }^{13} \mathrm{C}\right.$, Supelco) were added to the live ${ }^{13} \mathrm{C}$-labeled utilization experiments. After the CO substrate addition, the naturally occurring $\mathrm{CO}$ made up at most $0.02 \%$ of the total substrate concentration. Approximately $2 \mathrm{~mL}$ of lab air were added to all twelve bottles, to keep the experiments aerobic $\mathrm{O}_{2}$ and $\mathrm{CO}$ were distributed throughout the gas and liquid phases by continually shaking the bottles, having a 1:3 headspace to liquid ratio, and having a relatively large liquid surface area $\left(12 \mathrm{~cm}^{2}\right)$ in contact with the headspace. The concentrations of gases in the headspace were monitored over time on days $1,2,3,8,29,50$, and 59 days after CO was added. On day 59 the sediments and water were extracted for Phospholipid fatty acids (PLFA).

\section{ANALYTICAL METHODS}

\section{Gaseous concentrations and $\delta{ }^{13} \boldsymbol{C}$}

Concentrations of $\mathrm{CO}, \mathrm{CH}_{4}$, and $\mathrm{CO}_{2}$ in the headspace of the experimental bottles were measured using a SRI gas chromatograph (GC) equipped with a flame ionization detector (FID) and a methanizer. Gases were separated using a Carboxen 1010 column $(30 \mathrm{~m} \times 0.32 \mathrm{~mm}, 30 \mu \mathrm{m})$ and the following temperature 
program: $40^{\circ} \mathrm{C}$ hold $6 \mathrm{~min}$, ramp $25^{\circ} \mathrm{C} / \mathrm{min}$ to $150^{\circ} \mathrm{C}$, hold $6 \mathrm{~min}$ at $150^{\circ} \mathrm{C} . \mathrm{O}_{2}$ concentrations in the headspace of the experimental bottles were determined using an Agilent 6890 GC equipped with a thermal conductivity detector (TCD) and using a $\mathrm{N}_{2}$ carrier gas. $\mathrm{O}_{2}$ was separated from other gases using the same column held at $40^{\circ} \mathrm{C}$ isothermal. A mixed gas standard (Scotty 14) was used for calibration curves. The Scotty Gas Standard contained $5.00 \%$ of $\mathrm{O}_{2}, 5.00 \%$ of $\mathrm{N}_{2}, 5.00 \%$ of $\mathrm{CO}, 4.01 \%$ of $\mathrm{CH}_{4}, 4.00 \%$ of $\mathrm{H}_{2}$, and $5.00 \%$ of $\mathrm{CO}_{2}$ in a balance of He. The detection limits for $\mathrm{CO}$, $\mathrm{CH}_{4}$, and $\mathrm{CO}_{2}$ in the gas phase were $10,1.3$, and $10 \mu$ moles/L, respectively. Precision on triplicate injections of the standard was always less than 5\% RSD.

The compound-specific carbon isotopic composition $\left(\delta^{13} \mathrm{C}\right)$ of $\mathrm{CO}, \mathrm{CO}_{2}$, and $\mathrm{CH}_{4}$ was measured by gas chromatographycombustion-isotope ratio mass spectrometry (GC/IRMS; Agilent $6890 \mathrm{~N}$ GC, Thermo Conflo III interface, Thermo Delta V+ IRMS). The gases were separated in the GC using a Carboxen 1010 capillary column $(30 \mathrm{~m} \times 0.32 \mathrm{~mm}) . \delta^{13} \mathrm{C} \mathrm{CO}$ was analyzed using the following temperature program: $40^{\circ} \mathrm{C}$ hold for $6 \mathrm{~min}$, then $\mathrm{ramp} 25^{\circ} / \mathrm{min}$ to $110^{\circ} \mathrm{C}$, while $\mathrm{CO}_{2}$ and $\mathrm{CH}_{4}$ samples were analyzed using an isothermal temperature programme $\left(110^{\circ} \mathrm{C}\right)$. Samples were taken from the microcosm bottles using a $0.025-0.5 \mathrm{~mL}$ gas syringe. Due to the change of concentrations, sample injection size varied $(0.01-0.5 \mathrm{~mL})$ per gas. Internal stable carbon isotope standards were used for $\mathrm{CO}, \mathrm{CH}_{4}$, and $\mathrm{CO}_{2}$. The total analytical error associated with stable carbon isotope analysis by this method is $\pm 0.5 \%$. Isotope ratios were reported in delta notation $\left(\delta^{13} \mathrm{C}\right)$ and were calculated relative to international standards V-PDB for carbon isotopes:

$$
\delta^{13} \mathrm{C}=\left(\mathrm{R}_{\mathrm{sam}} / \mathrm{R}_{\mathrm{std}}-1\right)
$$

where $R_{\text {sam }}$ and $R_{\text {std }}$ are the ratio of heavy to light isotopes (i.e., ${ }^{13} \mathrm{C} /{ }^{12} \mathrm{C}$ ) for the sample and standard, respectively (Coplen, 2011).

\section{Phospholipid fatty acids extraction and identification}

Phospholipid fatty acids (PLFA) were extracted according to a recently described protocol (Ziegler et al., 2013) based on the Bligh and Dyer process, modified for as follows: (1) experimental bottles were frozen and freeze-dried prior to extraction, and the extraction of polar lipids was conducted directly in the bottles; (2) the extraction was scaled down to a total extractant volume of $76 \mathrm{~mL}$ in 3 extraction steps; (3) samples were sonicated for $20 \mathrm{~min}$ prior to each extraction step, and decanted instead of centrifuged; and (4) phospholipids were eluated from silica columns with $6 \mathrm{~mL}$ methanol $(\mathrm{MeOH})$ and $6 \mathrm{~mL}$ dichloromethane:MeOH:water (3:5:2) to optimize the recovery of phosphatidylcholines (Mills and Goldhaber, 2010).

Phospholipid fatty acids were transesterified into fatty acid methyl esters (FAMEs) by mild alkanolysis, spiked with an internal standard ( $2 \mu \mathrm{g}$ ethyl eicosanoate), and quantified by gas chromatography/flame ionization detection (GC/FID; Agilent 6890A). FAMEs were separated on a BPX70 column $(50 \mathrm{~m}$ length, $\times 0.22 \mathrm{~mm}$ inner diameter $\times 0.25 \mu \mathrm{m}$ film thickness; SGE Analytical Sciences). The GC oven temperature was initially increased from 70 to $160^{\circ} \mathrm{C}$ at $10^{\circ} \mathrm{C} \mathrm{min}^{-1}$, held for $5 \mathrm{~min}$, then increased at $4^{\circ} \mathrm{C} \mathrm{m^{-1 }}$ to $260^{\circ} \mathrm{C}$ and held at $260^{\circ} \mathrm{C}$ for $15 \mathrm{~min}$. FAMEs were identified with gas chromatography/mass specific detection (GC/MSD; Agilent 6890N GC with 5975C MSD), applying the same chromatographic conditions.

The compound-specific carbon isotopic composition $\left(\delta^{13} \mathrm{C}\right)$ of FAMEs was measured by gas chromatography-combustionisotope ratio mass spectrometry (GC/IRMS; Agilent 6890N GC, Thermo Conflo III interface, Thermo Delta V+ IRMS). The same chromatographic conditions as used for GC/FID were applied except that a GC column with $0.32 \mathrm{~mm}$ internal diameter was used. Each sample was analyzed three times. IRMS performance was monitored by periodic analysis of an external reference standard containing 8 fatty acid methyl and ethyl esters (Mixture "F8."A. Biogeochemical laboratories, University of Indiana) and constancy of the measured isotopic composition of the internal standard. The $\delta^{13} \mathrm{C}$ of the $\mathrm{MeOH}$ used for transesterification was determined with a TOC analyzer coupled to an isotope ratio mass spectrometer (OI Analytical Aurora 1030W; Finnigan Delta Plus XP; G. G. Hatch Stable Isotope Laboratory, University of Ottawa) and used to corrected the measured $\delta^{13} \mathrm{C}$ values of FAMEs for $\mathrm{MeOH}$ derived carbon.

\section{STATISTICAL ANALYSIS}

Differences in the abundance and composition of PLFA between live and killed treatments in the CO utilization experiments were tested using Welch's $t$-tests. Concentration or composition of PLFA were tested for significant differences between live bottles (both ${ }^{13} \mathrm{C}$-labeled and non-labeled) and killed bottles. The calculations were conducted using Libre Office V. 4.1.3.2. Due to the low number of replicates we report all $p<0.1$.

\section{RESULTS}

\section{GEOCHEMICAL CHARACTERIZATION OF WHC2}

Aqueous geochemical parameters of the water at the WHC2A discharge point were determined in 2011 and 2012, and the recharge water (i.e., new pool water after repeated emptying of the pool) was also sampled at the WHC2A discharge location in 2012 (Table 1). The geochemical parameters (e.g., $\mathrm{pH}$, dissolved $\mathrm{H}_{2}$, and dissolved $\mathrm{CH}_{4}$ concentrations and $\delta^{13} \mathrm{C}$ values) of the pool water changed very little from 2011 to 2012. Nutrient concentrations, nitrate and sulfate, and TIC concentrations in the recharge water were all very low compared to the adjacent Winter House Brook (Table 1). The recharge water had similar $\mathrm{pH}$, dissolved $\mathrm{H}_{2}$, dissolved $\mathrm{CH}_{4}$, and phosphate values to the pool waters. The concentrations of TIC, nitrate, and sulfate, however, were lower in the recharge water compared to the pool water, while organic acid concentrations were higher in the recharge water compared to the pool water (Table $\mathbf{1}$ ).

\section{BACTERIAL DIVERSITY OF WHC2}

Betaproteobacteria belonging to the Comamonadaceae family dominated the WHC2 pool water samples collected in 2012 (Figure 2), which is consistent with previously published results from WHC2 pool samples collected in 2010 and 2011 (Brazelton et al., 2013). Metagenomic sequences affiliated with this Comamonadaceae-affiliated taxon, for which (Suzuki et al., 
Table 1 | Geochemical characterization of ultra-basic pool, spring recharge, and brook from 2011 to 2012.

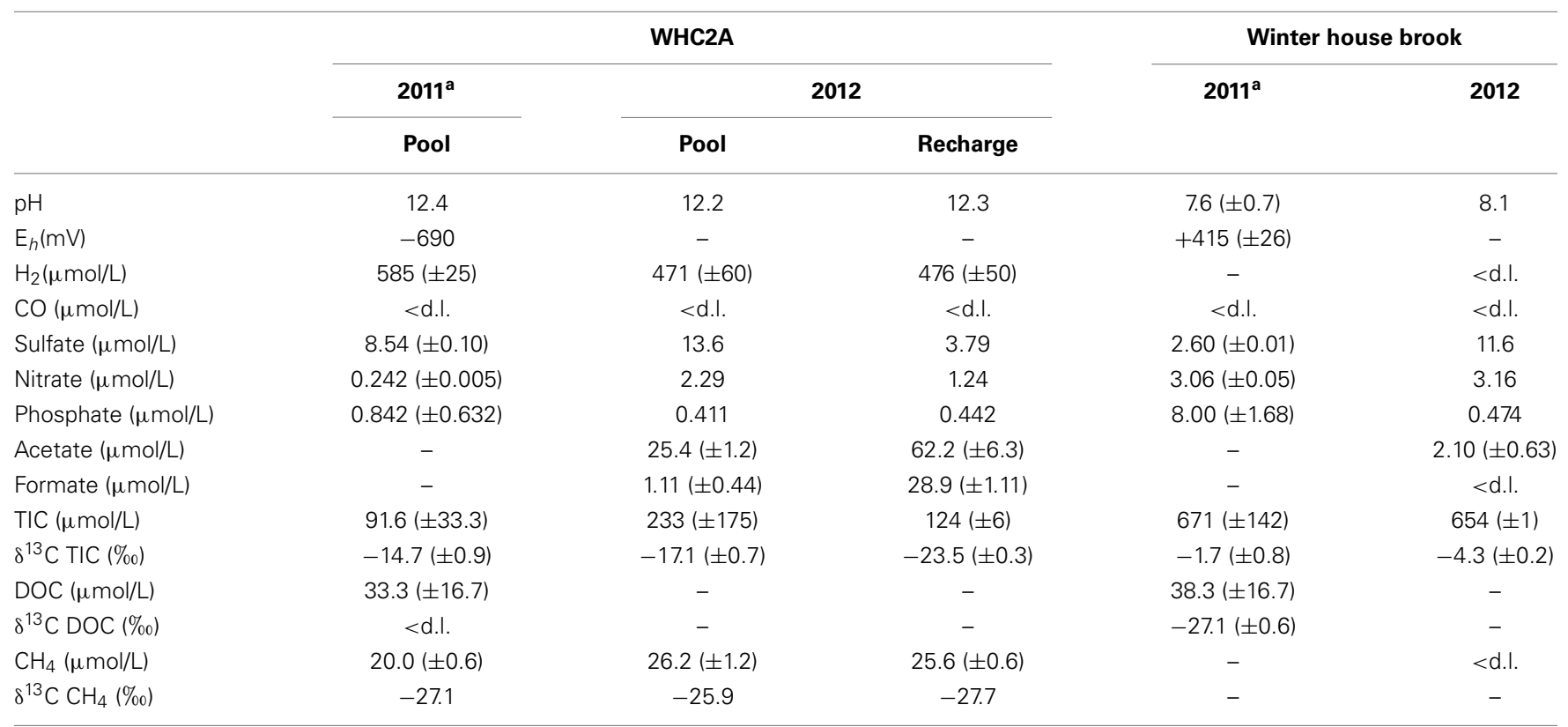

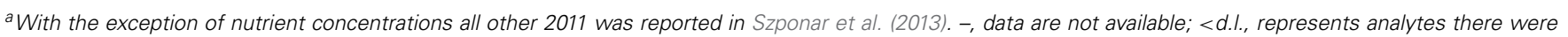
below the detection limits of the analysis.

2014) have proposed the genus name Serpentinomas, encode proteins involved in CO utilization and carbon fixation via Rubisco (Brazelton et al., 2012). Interestingly, the Comamonadaceae sequences comprised a somewhat smaller proportion of the bacterial community in the post-recharge pool (i.e., immediately after it was emptied several times), suggesting that they are not enriched in the subsurface (Figure 2). These sequences are very rare in the upstream surface water source, so they are not derived from surface water, either. These observations indicate that the Comamonadaceae organisms thrive in the mixing zone where subsurface ultra-basic fluids meet surface waters and perhaps atmospheric gases, which is consistent with previous results (Brazelton et al., 2012, 2013).

The bacterial compositions of carbonate-rich sediments collected from the bottom of the WHC2 pool also appear to represent a mixture of subsurface and surface materials. Each sediment sample has a large representation of Comamonadaceae, indicating that both sediments and overlying fluids are potential habitats for these organisms.

\section{METHANOGENESIS EXPERIMENTS USING ORGANIC ACIDS AND BICARBONATE SUBSTRATES}

$\mathrm{CH}_{4}$ was detected in only 7 of the 15 experimental treatments (Figure 3). The $\mathrm{CH}_{4}$ was detected in live and killed treatments, as well as ${ }^{13} \mathrm{C}$-labeled and non-labeled substrate addition treatments. All $\mathrm{CH}_{4}$ had similar values, averaging $-26.7 \pm 0.7 \%$, including the ${ }^{13} \mathrm{C}$-labeled substrate addition experiments. The average $\delta^{13} \mathrm{C}_{\mathrm{CH} 4}$ value from the experiments was indistinguishable from the average $\delta^{13} \mathrm{C}_{\mathrm{CH} 4}$ value, $-26.9 \pm 0.9 \%$, (Table 1) determine from field samples. Therefore, there is no clear evidence of microbial production of $\mathrm{CH}_{4}$ using the substrates added in these treatments.

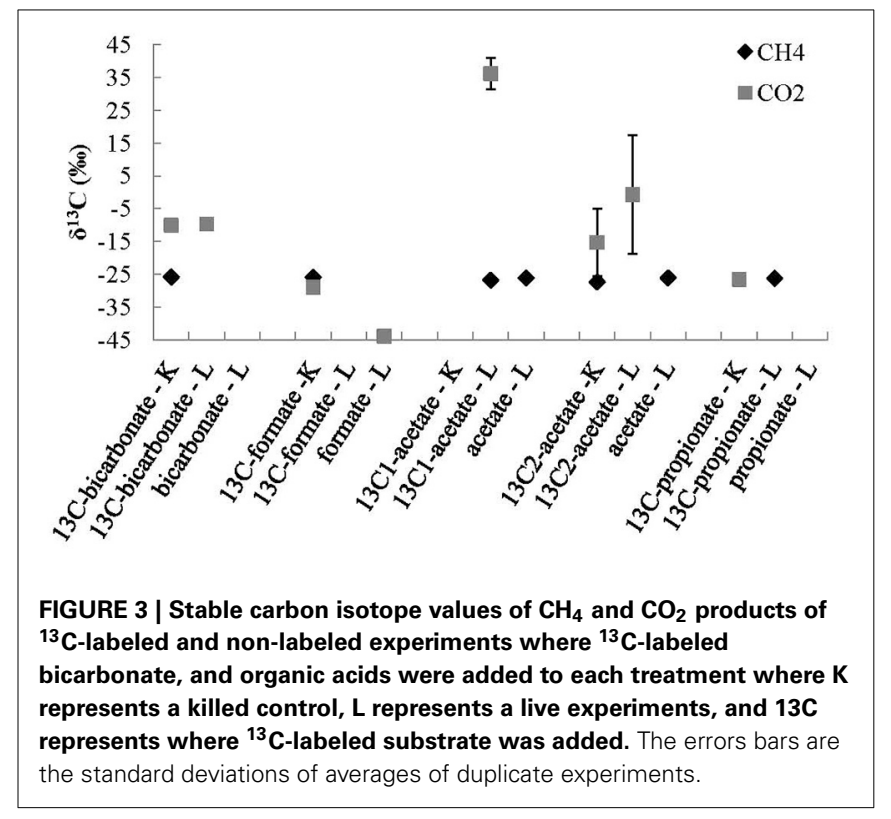

The concentration of $\mathrm{CO}_{2}$ was below the detection limit in many of the experiments, this was expected in the live treatments because the dominant species of inorganic carbon at high $\mathrm{pH}$ values is the carbonate ion, not the $\mathrm{CO}_{2}$ gas. $\mathrm{CO}_{2}$ was detected in all of the acidified killed control experiments, this was also expected because the dominant species of inorganic carbon at low $\mathrm{pH}$ values is $\mathrm{CO}_{2}$ gas (Figure 3). The $\mathrm{CO}_{2}$ measured in the ${ }^{13} \mathrm{C}$-labeled bicarbonate addition experiments, was more enriched in ${ }^{13} \mathrm{C}$ than the TIC measured from the field samples (Table 1), reflecting the ${ }^{13} \mathrm{C}$-labeled bicarbonate that was added to each of these bottles. 
In the killed ${ }^{13} \mathrm{C}$-labeled organic acid addition controls, the $\delta^{13} \mathrm{C}$ of the $\mathrm{CO}_{2}$ was similar $\delta^{13} \mathrm{C}$ of the TIC sampled from the recharge in the field (Table 1 ). In the live ${ }^{13} \mathrm{C}$-labeled acetate treatments, where the carboxyl-carbon $\left(\mathrm{CH}_{3}^{13} \mathrm{COO}^{-}\right)$was labeled with ${ }^{13} \mathrm{C}$ there was a production of $\mathrm{CO}_{2}$ in one replicate extetainer that was enriched in ${ }^{13} \mathrm{C}\left(\delta^{13} \mathrm{C}_{\mathrm{CO} 2}=+36.1 \%\right)$ compared to other organic acid addition experiments (Figure 3 ). The very ${ }^{13} \mathrm{C}$ enriched $\mathrm{CO}_{2}$ in one of the live ${ }^{13} \mathrm{C}_{\mathrm{C} 1}$-labeled acetate addition treatments suggests that the carboxyl-carbon of the acetate molecule was converted to $\mathrm{CO}_{2}$ via heterotrophic respiration in that experimental bottle.

\section{CO UTILIZATION EXPERIMENTS}

$\mathrm{CO}$ concentrations were monitored in all of the nine CO utilization experimental bottles (three live ${ }^{13} \mathrm{C}$-labeled substrates, three live, and three killed non-labeled controls). The headspace was sampled for CO concentrations on days 2, 3, 4, 9, 30, 51, and 60 of the experiment. Concentration changes relative to day 2 measurements are shown in Figure 4. The concentrations of CO slightly increased in all live experiments on day 3 , probably due to incomplete $\mathrm{CO}$ equilibration on day 2. Subsequently, CO concentrations decreased in all of the live bottles. By day 60, there was no detectable $\mathrm{CO}$ in the live ${ }^{13} \mathrm{C}$-labeled experiments. In the live nonlabeled experiments the concentration of CO decreased by $59 \%$ in one bottle, and 65\% in another. The 3rd live non-labeled was accidentally vented on day 30 , such that no data could be obtained after day 9 for this experiment. However, on day 9 the concentration of CO in this bottle had decreased by $15 \%$, comparable to the other non-labeled bottles.

Similar to the concentrations of $\mathrm{CO}$ in the live experiments, the $\mathrm{CO}$ concentrations in the killed controls increased on day 3. However, unlike the live experiments, the $\mathrm{CO}$ concentrations in all of the killed bottles remained high for the remainder of the experiment. All of the increases and decreases were replicated in all three killed bottles. Overall the concentrations in the killed controls were always greater than the concentration measured on day 2 of the experiment.

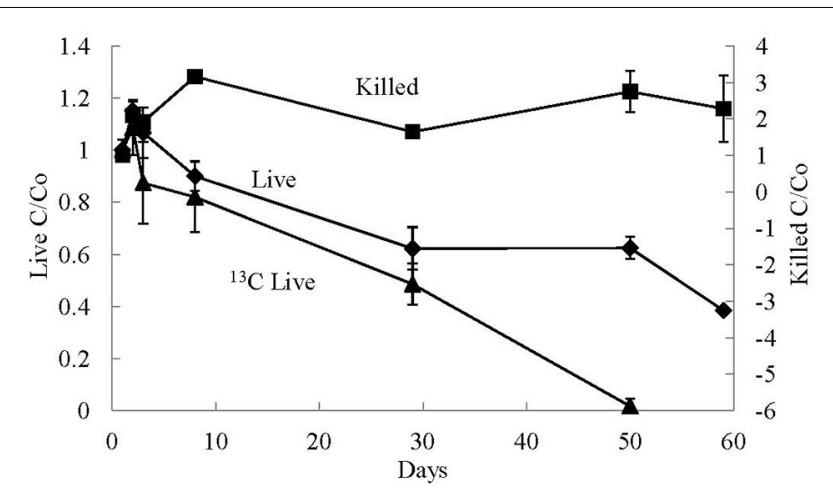

FIGURE 4 | Average relative gaseous $\mathrm{CO}$ concentrations (C/Co) measured over time in the $\mathrm{CO}$ addition experiments. Experimental treatments included killed control (Killed), live non-labeled (Live), and ${ }^{13} \mathrm{C}$-labeled CO (13C Live). The error bars are the standard deviation of the average value of the triplicate treatments.
$\mathrm{O}_{2}$ was present in the headspace of all $\mathrm{CO}$ addition experiments; however, the $\mathrm{O}_{2}$ concentrations in the headspace decreased over time in the live experiments, such that by day 60 there was on average $29 \pm 10 \mu$ moles/ $\mathrm{L}$ of $\mathrm{O}_{2}$ gas in the headspace of the live $\mathrm{CO}$ addition experiments and $136 \pm 27 \mu$ moles/L of $\mathrm{O}_{2}$ gas in the headspace of the killed control experiments, such that there was approximately $79 \%$ less $\mathrm{O}_{2}$ in the live experiments compared to the killed controls on day 60 . Therefore, the CO microbial utilization most likely occurred in an oxygenated environment.

The average starting $\delta^{13} \mathrm{C}$ of $\mathrm{CO}$ in the non-labeled experiments was $-44.4 \pm 0.5 \%$. Over the course of the experiments the $\delta^{13} \mathrm{C}$ of $\mathrm{CO}$ in the live experiments became less negative with an average increase of $10 \pm 0.3 \%$ between day 2 and day 60 (Figure 5). This isotopic enrichment in ${ }^{13} \mathrm{C}$ corresponds to a $59-65 \%$ decrease in the CO concentrations in these experiments. Conversely, over the course of the killed non- ${ }^{13} \mathrm{C}$-labeled control experiments, the $\delta^{13} \mathrm{C}$ of $\mathrm{CO}$ increased on average by $1.3 \pm 0.2 \%$ between day 2 and day 60, and there was no decrease in relative $\mathrm{CO}$ concentrations over this period of time.

At the end of the CO utilization experiments, all bottles were frozen for PLFA identification, quantification, and stable isotope analysis (Table 2). Of the three live non-labeled bottles, one broke during freezing, so only two live non-labeled bottles were available for analysis. PLFA extractions yields were between 8.0 and $25.4 \mathrm{nmol}$ PLFA per bottle, with slightly higher yields in live experiments compared to the killed controls $(18.6 \pm 4.8$ and $12.3 \pm 3.8 \mathrm{nmol} ; t=-2.03, P=0.096$ [Welch's $T$-test]) (Table 2). PLFA composition was dominated by $18: 1 \omega 7$, which made up 26.2-34.1 mol\% of all PLFA. $6.9-15.0 \mathrm{~mol} \%$ of the PLFA composition was made up of 16:0, 16:1 $1 \omega 7$, cy17:0, 18:0, $18: 1 \omega 9$. While cy 19:0 as well as smaller amounts (3.3-5.4 mol\%) of 20:0 and 22:0 made up the residual PLFA composition. There was no difference in PLFA composition between live experiments and the killed controls except for a higher abundance of 18:1w7 and

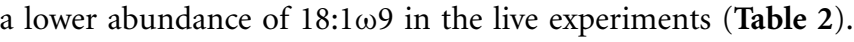

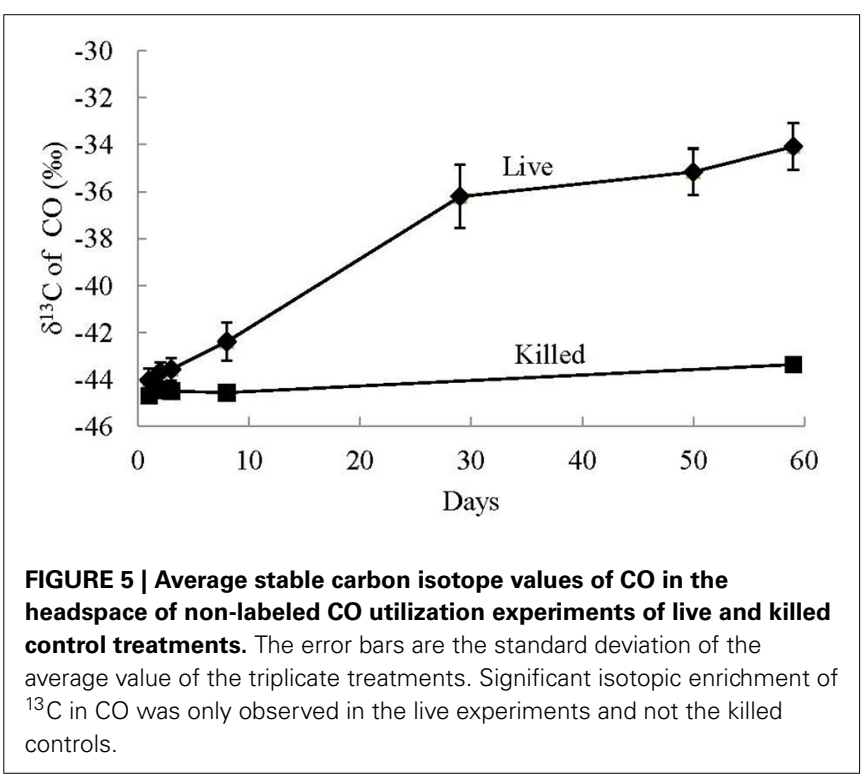


Table 2 | Average PLFA total concentrations, mol\%, and $\delta^{13} \mathrm{C}$ values from ${ }^{13} \mathrm{C}$-labeled and non-labeled $\mathrm{CO}$ utilization experiments from triplicate experiments except where noted.

\begin{tabular}{|c|c|c|c|c|c|c|c|}
\hline & \multicolumn{4}{|c|}{ Live } & \multicolumn{2}{|c|}{$\begin{array}{c}\text { Killed } \\
\text { Natural abundance CO }\end{array}$} & \multirow{2}{*}{$\begin{array}{c}\text { Welch } T \text {-test } \\
*_{*} \\
\text { (p-value) }\end{array}$} \\
\hline & Mean & $S D$ & Mean & $S D$ & Mean & $S D$ & \\
\hline Sum of PLFA (nmol bottle ${ }^{-1}$ ) & 15.3 & 2.8 & 20.8 & 5.0 & 12.3 & 3.8 & 0.096 \\
\hline \multicolumn{8}{|l|}{ PLFA COMPOSITION (mol\%) } \\
\hline cy17:0 & $7.1 \%$ & $0.6 \%$ & $7.8 \%$ & $1.4 \%$ & $7.8 \%$ & $0.5 \%$ & 0.647 \\
\hline 18:0 & $11.9 \%$ & $2.6 \%$ & $10.3 \%$ & $1.9 \%$ & $10.9 \%$ & $0.8 \%$ & 0.953 \\
\hline $18: 1 \omega 9$ & $9.2 \%$ & $0.7 \%$ & $8.3 \%$ & $1.2 \%$ & $12.1 \%$ & $1.8 \%$ & 0.062 \\
\hline $18: 1 \omega 7$ & $34.1 \%$ & $0.3 \%$ & $30.0 \%$ & $2.2 \%$ & $26.2 \%$ & $3.2 \%$ & 0.079 \\
\hline cy19:0 & $9.7 \%$ & $0.5 \%$ & $7.9 \%$ & $1.1 \%$ & $10.4 \%$ & $1.5 \%$ & 0.161 \\
\hline \multicolumn{8}{|l|}{ PLFA $\delta^{13} \mathbf{C}$} \\
\hline $16: 1 \omega 7$ & $-36.0 \%$ & $2.7 \%$ & $-22.4 \%$ & $9.4 \%$ & $-29.2 \%$ & $7.6 \%$ & \\
\hline cy17:0 & $-26.7 \%$ & $0.6 \%$ & $-25.3 \%$ & $1.1 \%$ & $-24.6 \%$ & $1.1 \%$ & \\
\hline $18: 1 \omega 9$ & $-25.8 \%$ & $0.8 \%$ & $-25.0 \%$ & $0.5 \%$ & $-25.8 \%$ & $0.4 \%$ & \\
\hline $18: 1 \omega 7$ & $-24.2 \%$ & $0.1 \%$ & $-24.8 \%$ & $0.9 \%$ & $-25.2 \%$ & $0.4 \%$ & \\
\hline cy19:0 & $-27.0 \%$ & $0.2 \%$ & $-26.9 \%$ & $1.0 \%$ & $-27.2 \%$ & $0.6 \%$ & \\
\hline
\end{tabular}

${ }^{*}$ The average of two live non ${ }^{13} \mathrm{C}$-labeled treatments, $L 2=13.3$ nmole and $L 3=17.3$ nmole. The $L 1$ bottle broke during freezing.

${ }^{* *}$ Welch T-tests compared live $(n=5)$ vs. killed $(n=3)$ experiments.

Bold p-values are values less than 0.1 .

The PLFA in killed controls likely originate from the microbial community present at the beginning of the experiment, either as part of the in situ community in the carbonate sediment, or grown during pre-incubation. Noteworthy, PLFA persisted in the killed controls over a prolonged period (60 days) even though $\mathrm{pH}$ was lowered to $\sim 1$. In contrast, the increase of biomass due to microbial growth during $\mathrm{CO}$ addition the experiments was either absent or very limited and not associated with a major change in PLFA composition.

The detected PLFA were either non-specific (e.g., 16:0, 18:0, $18: 1 \omega 9,20: 0,22: 0)$ or typically associated with Gram negative bacteria $(16: 1 \omega 7,18: 1 \omega 7$, cy17:0, cy19:0) supporting the dominance of Hydrogenophaga-related organisms. Noteworthy, terminally branched PLFA (e.g., iso and ante-iso 15:0) characteristic for Gram positive bacteria were not detected, even though metagenomic studies of the spring found high abundances of Erysipeloceae, a family within the Gram positive phylum Firmicutes.

For the most part the $\delta^{13} \mathrm{C}$ of the PLFAs were similar in the live ${ }^{13} \mathrm{C}$-labeled $\mathrm{CO}$ compared to the live non-labeled $\mathrm{CO}$ experiments [i.e., incubated with $\mathrm{CO}$ with a natural abundance of $\left.{ }^{13} \mathrm{C} /{ }^{12} \mathrm{C}\left({ }^{13} \mathrm{C}_{\mathrm{CO}}=-44.4 \% 0\right)\right]$ with the majority of individual PLFA (i.e., cy17:0, 18:1 $\omega 7,18: 1 \omega 9$, and cy19:0) having well constrained $\delta^{13} \mathrm{C}$ values between -27.2 and $-24.2 \% 0$ in all treatments (Table 2, Figure 6). However, the uptake of the ${ }^{13} \mathrm{C}$ into two individual PLFAs was detected, indicating that some microbial taxa incorporated $\mathrm{CO}$ into their biomass while others did not (Table 2, Figure 6). The PLFA associated with gram negative bacteria, 16:1 1 7, had more negative $\delta^{13} \mathrm{C}$ than other PLFA in live non ${ }^{13} \mathrm{C}$ CO-labeled experiments $(-38.0 \pm 3.5 \%$ and $-34.1 \pm$ $0.4 \% 0$ ), likely due to the very negative $\delta^{13} \mathrm{C}$ of the $\mathrm{CO}$ used for the experiment $(-44.4 \%)$, and less negative but variable $\delta^{13} \mathrm{C}$ values in live microcosms incubated with ${ }^{13} \mathrm{C}$-labeled CO $(-29.5 \pm$ $0.5 \%,-26.0 \pm 0.5 \%$, and $-11.8 \pm 0.5 \% 0$ ). The same trend was present in the non-specific PLFA, 16:0, but to a much lesser extent (Table 2, Figure 6). Additionally, the $\delta^{13} \mathrm{C}$ of $16: 0$ and $16: 1 \omega 7$ were highly correlated $(R=0.94, p=0.0005)$. However, the difference in $\delta^{13} \mathrm{C}$ between labeled and non-labeled experiments (up to $26 \%$ ) was very low compared to the high concentration in ${ }^{13} \mathrm{C}$ in $\mathrm{CO}$ in the labeled microcosms which was greater than $2800 \%$, indicating that carbon that resulted from CO fixation made up $<1 \%$ of PLFA.

\section{DISCUSSION}

\section{LACK OF EVIDENCE FOR MICROBIAL METHANOGENESIS AT SITES OF PRESENT-DAY CONTINENTAL SERPENTINIZATION}

The results from the bicarbonate and organic acid addition experiments showed no microbial production of methane via autotrophic or organic acid fermentive pathways. Therefore, if methanogens utilizing these substrates are present in the spring fluids they are either not active, not active in very specific environments that were created in the lab, or that the methane production is very slow. These results support a previous geochemical study of $\mathrm{CH}_{4}$ and higher molecular weight hydrocarbons at the 


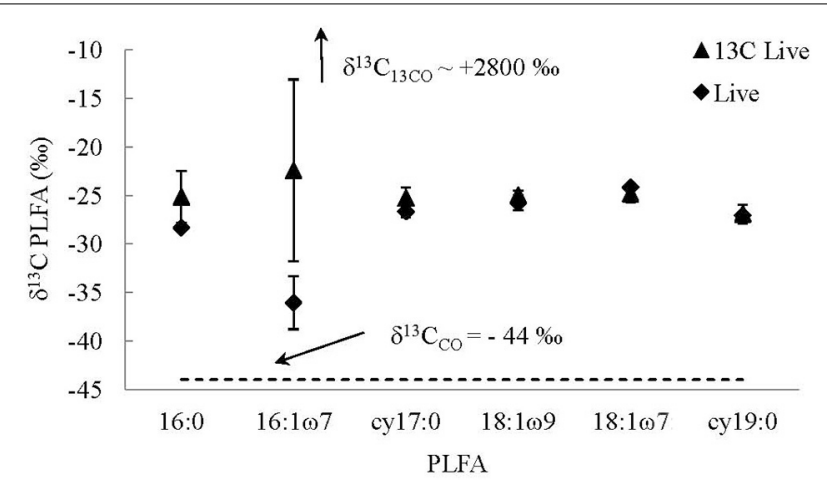

FIGURE 6 | Average $\delta^{13} \mathrm{C}$ of PLFAs from live ${ }^{13} \mathrm{C}$-labeled $\mathrm{CO}$ (13C Live) and live non-labeled $\mathbf{C O}$ (Live) treatments. The values reported for the live ${ }^{13} \mathrm{C}$-labeled treatments are average values of replicate experiments, while the values reported for the live treatments are an average of two bottles, as one broke during freezing. The error bars are the standard deviations of the averages.

Tablelands' WHC2 pool (Szponar et al., 2013). Szponar et al. (2013) concluded that the primary source of dissolved methane in the WHC2 pool was not microbial, but most likely thermogenic or abiogenic in origin. This conclusion was based on carbon isotope values and gaseous compositions more similar to those previously found for thermogenic and abiogenic gases. This observation was consistent with initial microbiological studies of the Tablelands spring fluids, which were unable to detect archaeal $16 \mathrm{~S}$ ribosomal RNA genes in Tablelands fluids via the polymerase chain reaction (Brazelton et al., 2013). Additionally, metagenomic sequences predicted to represent methanogens comprised only $0.2 \%$ of all metagenomic sequences from WHC2B in 2010 (Brazelton et al., 2012). Therefore, if methanogens were present in the WHC2 pool they were extremely rare. Less common microbial methane substrates, methanol, methylamines, and dimethyl sulfide, were not tested in these experiments; however, their potential contributions to microbial methane should be tested.

\section{MICROBIAL CO UTILIZATION AT SITES OF PRESENT-DAY CONTINENTAL SERPENTINIZATION}

In addition to carbonate, $\mathrm{CO}$ may also be used as a carbon substrate for autotrophic metabolisms in high $\mathrm{pH}$ environments. The results from the $\mathrm{CO}$ utilization experiments demonstrated that $\mathrm{CO}$ was utilized by microorganisms from the WHC2 pool. Unlike $\mathrm{CO}_{2}$, whose speciation is $\mathrm{pH}$ dependant, $\mathrm{CO}$ does not readily participate in hydrolysis reactions (i.e., reactions with $\mathrm{H}^{+}$) and therefore $\mathrm{CO}$ concentration/speciation is not dependent on $\mathrm{pH}$. The $\mathrm{CO}$ oxidizing enzyme, carbon monoxide dehydrogenase $(\mathrm{CODH})$, was detected in WHC2 pool fluids (Brazelton et al., 2012). This enzyme is used by organisms that utilize CO as their electron donor and their carbon source.

The results from the $\mathrm{CO}$ utilization experiments demonstrated that $\mathrm{CO}$ was utilized by microorganisms from the WHC2 pool. In the non-labeled $\mathrm{CO}$ experiments, the residual $\mathrm{CO}$ concentration decreased on average $62 \%$ over 60 days in live experiments. At the same time, the residual CO became on average $10.1 \pm$

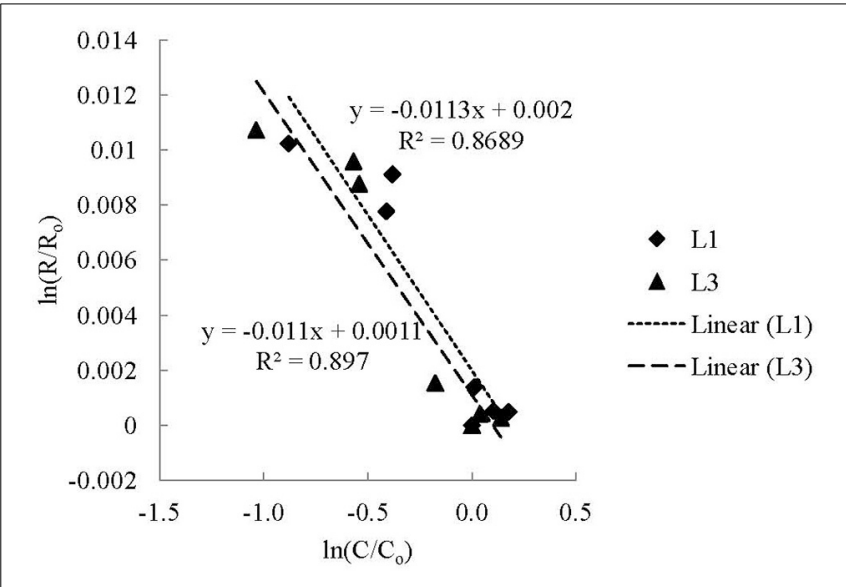

FIGURE 7 | The kinetic isotope effect (KIE) of microbial CO utilization using a Rayleigh Distillation Equation (RDE) (Mariotti et al., 1981). The fractionation factor $(\alpha)$ is equal to 1 plus the slope of a linear regression of $\ln (\mathrm{R} / \mathrm{Ro})$ vs. $\ln (\mathrm{C} / \mathrm{Co})$ determined from experimental data, where $R_{0}$ is the initial isotopic ratio $\left({ }^{13} \mathrm{C} /{ }^{12} \mathrm{C}\right)$ of the $\mathrm{CO}$ and $R$ is the isotopic ratio of the $\mathrm{CO}$ at time $t$, and $\mathrm{C}_{0}$ is the initial concentration of $\mathrm{CO}$ and $\mathrm{C}$ is the concentration of $\mathrm{CO}$ at time $t$ (Scott et al., 2004). Fractionation factors are often reported as enrichment values $[\varepsilon=1000 \times(\alpha-1)]$.

$1.5 \%$ more enriched in ${ }^{13} \mathrm{C}$ in the live non-labeled $\mathrm{CO}$ experiments. Therefore, there was most likely a biological process occurring whereby $\mathrm{CO}$ containing ${ }^{12} \mathrm{C}$ was utilized faster than CO containing ${ }^{13} \mathrm{C}$ causing the ${ }^{13} \mathrm{C} /{ }^{12} \mathrm{C}$ ratio of the residual $\mathrm{CO}$ to increase over time. The kinetic isotopic fractionation can be determined using the Rayleigh Distillation Equation (RDE) (Figure 7). The isotopic enrichment factor determined for both live non-labeled $\mathrm{CO}$ addition experiments were fairly consistent $(-11.3$ and $-11.0 \%$ ) (Figure 7$)$, demonstrating that the isotopic fractionations in both experiments were consistent. The correlation coefficients for the regression lines were 0.8792 and 0.8970 , indicating that the data were well described by the RDE in both experiments; however, the high $R^{2}$ values are driven by binomial dispersion of the data (Figure 7). Additional experiments should be performed to continue to quantify the kinetic isotope fractionation of the microbial CO utilization in these systems. The RDE applied to the killed controls had very poor correlation coefficients for the regression lines (averaging 0.1608). This is not surprising as the $\delta^{13} \mathrm{C}$ of CO remained fairly constant in the killed controls, while the concentrations varied.

This is the first study to report CO consumption and its isotopic enrichment factors in ultra-basic springs associated with present-day serpentinization. There are few measurements of the isotopic enrichment factors of biological uptake of $\mathrm{CO}$ to compare this value to; however, the values estimated in this study are slightly larger compared to other microbial CO utilization studies. For example, the enrichment factors determined during $\mathrm{CO}$ consumption in soil was determined to be $-8 \%$ (Tsunogai et al., 2002), while the isotopic enrichment factor during marine microbial oxidation of CO was $-5 \%$ (Nakagawa et al., 2004).

The PLFA data from the ${ }^{13} \mathrm{C}$-labeled CO utilization experiments indicated some microbial uptake of CO (Table 2). The total amount of PLFA (nmol/bottle) were slightly higher in the live 
experiments compared to the killed controls. The PLFA identified were the same in both the live experiments and killed controls, and there was no difference in PLFA composition between live experiments and the killed controls except for a higher abundance

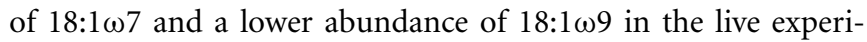
ments, indicating that there was little to no community change

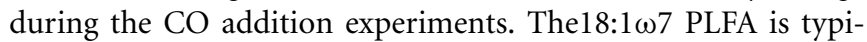

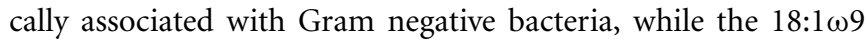
occurs widespread in bacteria and fungi (Zelles et al., 1992; Ruess and Chamberlain, 2010). However, ${ }^{13} \mathrm{C}$ isotopic enrichment in the live ${ }^{13} \mathrm{C}$-labeled CO utilization experiments was not

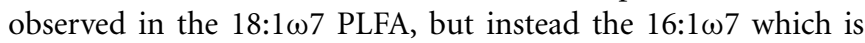
also associated with Gram negative bacteria. These results support limited incorporation of carbon from CO likely by Gram negative bacteria. Based on the assumption that $1 \%$ of the entire microbial biomass in the experiments was derived from $\mathrm{CO}$ carbon, less than $2 \%$ of the total CO carbon consumed in the experiments $(64.7 \mu \mathrm{g})$ was incorporated into the microbial biomass (based on $363.6 \mathrm{nmol}$ PLFA per mg biomass-C, Frostegård and Baath, 1996). This indicates that in our experiments, CO was used primarily as a source of energy, not biomass carbon. This might have resulted from the limited biomass increase during the experiment and/or because CO oxidizers utilized other carbon sources present in the ultra-basic fluid such as acetate and formate that were detected in the spring fluids (Table 1). However, PLFA carbon might have over-proportionally originated from acetate because acetyl-CoA is the universal precursor for fatty acid biosynthesis and therefore the incorporation of $\mathrm{CO}$ derived carbon into PLFA might underestimate the incorporation into overall biomass. Also, since microbial growth during the experiment was limited, turn-over of PLFA might under represent the turn-over of the bulk biomass. Nevertheless, even if this led to an underestimation of the carbon incorporation into biomass by an order of magnitude, CO-derived carbon would still account for only a small fraction of the total biomass or the total CO loss during the experiment.

The utilization of acetate and formate is supported by the field data. Acetate and formate concentrations were lower in the pool water compared to the recharging groundwater, while dissolved $\mathrm{H}_{2}$ concentration stayed the same in the pool and recharge waters (Table 1). This suggests that the acetate and formate were preferentially consumed in the pool, while $\mathrm{H}_{2}$ was not consumed in the pool. CO concentrations were not detected; however, this is not unexpected, because our CO detection limit $(\sim 10 \mu \mathrm{M})$ is orders of magnitude greater than the upper range of $\mathrm{CO}$ concentrations $(0.2-20 \mathrm{nmoles} / \mathrm{L})$ measured in groundwaters across the US (Chapelle and Bradley, 2007).

The Comamonadaceae which dominate the sediments and overlying fluids of the WHC2 pool (Figure 2) are Gram-negative bacteria, and they have been found at many sites of serpentinization and other high pH environments (Schrenk et al., 2013; Suzuki et al., 2014). Their closest characterized relatives include the Hydrogenophaga, which are aerobic or facultatively anaerobic. At least some Hydrogenophaga species can grow autotrophically on $\mathrm{H}_{2}$ or $\mathrm{CO}$ if organic carbon is not available (Willems et al., 1989). However, in the case of an environment where organic acids are present, like the Tablelands, it is possible that CO may be used as an electron donor by Hydrogenophaga-like bacteria but not as a carbon source for autotrophic growth. Unfortunately, $\mathrm{H}_{2}$ and organic acid concentrations were not monitored during our experiments; however, further experiments that control and monitor organic acids, $\mathrm{CO}$, and $\mathrm{H}_{2}$ concentrations should be performed.

\section{CONCLUSIONS}

Fluids discharging from sites of present-day continental serpentinization are ultra-basic, reducing, and low in electron acceptors, creating a challenging environment for life as we know it. However, once these fluids are discharged at the surface additional inputs such as oxygen and nutrients can enter the system, creating high redox gradient environments, which may no longer be nutrient limited. While the results from this study did not find evidence for microbial methanogenesis with organic acid and bicarbonate substrates, it did find empirical evidence in support of microbial $\mathrm{CO}$ utilization in agreement with earlier metagenomic studies. The CO utilization may be occurring when ultra-basic reducing waters associated with serpentinization mix with oxygenated surface waters. Microbial CO utilization may also occur at other sites where groundwater associated with serpentinization comes in contact with the atmosphere or mixes with oxygenated waters. For example, CO utilization may be possible at other serpentinization sites such as Cabeco de Vide, Portugal (Tiago and Verissimo, 2013), and The Cedars (Suzuki et al., 2014) where Hydrogenophaga-like organisms have been found.

\section{ACKNOWLEDGMENTS}

The authors would like to thank Mark Wilson for his inspirational support and great help over the years, and Geert Van Biesen and Jamie Warren for their laboratory expertise, and Robert Bazeley for his help in the field. This research was funded by Natural Science and Engineering Research Council (NSERC) Discovery Grant, and Canadian Space Agency, Field Investigations Program.

\section{SUPPLEMENTARY MATERIAL}

The Supplementary Material for this article can be found online at: http://www.frontiersin.org/journal/10.3389/fmicb. 2014.00613/abstract

\section{REFERENCES}

Abrajano, T. A., Sturchio, N., Kennedy, B. M., Lyon, G. L., Muehlenbachs, K., and Bohlke, J. K. (1990). Geochemistry of reduced gas related to serpentinization of the Zambales ophiolite, Philippines. Appl. Geochem. 5, 625-630. doi: 10.1016/0883-2927(90)90060-I

Albert, D. B., and Martens, C. S. (1997). Determination of low-molecular-weight organic acid concentrations in seawater and pore-water samples via HPLC. Mar. Chem. 56, 27-37. doi: 10.1016/S0304-4203(96)00083-7

Barnes, I., Lamarche, V. C., and Himmelberg, G. (1967). Geochemical evidence of present-day serpentinization. Science 156, 830-832. doi: 10.1126/science.156.3776.830

Blank, J. G., Green, S. J., Blake, D., Valley, J. W., Kita, N. T., Treiman, A., et al. (2009) An alkaline spring system within the Del Puerto Ophiolite (California, USA): a Mars analog site. Planet. Space Sci. 57, 533-540. doi: 10.1016/j.pss.2008.11.018

Brazelton, W. J., and Baross, J. A. (2010). Metagenomic comparison of two thiomicrospira lineages inhabiting contrasting deep-sea hydrothermal environments. PLoS ONE 5:e13530. doi: 10.1371/journal.pone.0013530

Brazelton, W. J., Morrill, P. L., Szponar, N., and Schrenk, M. O. (2013). Bacterial communities associated with subsurface geochemical processes in 
continental serpentinite springs. Appl. Environ. Microbiol. 79, 3906-3916. doi: 10.1128/AEM.00330-13

Brazelton, W. J., Nelson, B., and Schrenk, M. O. (2012). Metagenomic evidence for $\mathrm{H} 2$ oxidation and $\mathrm{H} 2$ production by serpentinite-hosted microbial communities. Front. Microbiol. 2:268. doi: 10.3389/fmicb.2011.00268

Brazelton, W. J., Schrenk, M. O., Kelley, D. S., and Baross, J. A. (2006). Methane- and sulfur-metabolizing microbial communities dominate the lost city hydrothermal field ecosystem. Appl. Environ. Microbiol. 72, 6257-6270. doi: 10.1128/AEM.00574-06

Caporaso, J. G., Lauber, C. L., Walters, W. A., Berg-Lyons, D., Huntley, J., Fierer, N., et al. (2012). Ultra-high-throughput microbial community analysis on the Illumina HiSeq and MiSeq platforms. ISME J. 6, 1621-1624. doi: 10.1038/ismej.2012.8

Chapelle, F. H., and Bradley, P. M. (2007). Hydrologic significance of carbon monoxide concentrations in ground water. Ground Water 45, 272-280. doi: 10.1111/j.1745-6584.2007.00284.x

Coplen, T. B. (2011). Guidelines and recommended terms for expression of stable-isotope-ratio and gas-ratio measurement results. Rapid Commun. Mass Spectrom. 25, 2538-2560. doi: 10.1002/rcm.5129

Fritz, P., Clark, I. D., Fontes, J. C., Whiticar, M. J., and Faber, E. (1992). "Deuterium and ${ }^{13} \mathrm{C}$ evidence for low temperature production of hydrogen and methane in a highly alkaline groundwater environment in Oman," in Proceedings of the 7th International Symposium on Water-Rock Interaction; Vol. 1, Low Temperature Environments. Proceedings-International Symposium on WaterRock Interaction. International Association of Geochemistry and Cosmochemistry and Alberta Research Council, Sub-Group on Water-Rock Interaction, eds Y. K., Kharaka, and A. S., Maest (Edmonton, AB: International), 793-796.

Frostegård, A., and Baath, E. (1996). The use of phospholipid fatty acid analysis to estimate bacterial and fungal biomass in soil. Biol. Fertil. Soils 22, 59-65. doi: $10.1007 /$ BF00384433

Hosgormez, H. (2007). Origin of the natural gas seep of Cirali (Chimera), Turkey: site of the first Olympic fire. J. Asian Earth Sci. 30, 131-141. doi: 10.1016/j.jseaes.2006.08.002

Huse, S. M., Mark Welch, D. B., Voorhis, A., Shipunova, A., Morrison, H. G., Eren, A. M., et al. (2014). VAMPS: a website for visualization and analysis of microbial population structures. BMC Bioinformatics 15:41. doi: 10.1186/1471-21 05-15-41

Kelley, D. S., Karson, J. A., Fruh-Green, G. L., Yoerger, D. R., Shank, T. M., Butterfield, D. A., et al. (2005). A serpentinite-hosted ecosystem: the lost city hydrothermal field. Science 307, 1428-1434. doi: 10.1126/science.11 02556

King, G. M., and Weber, C. F. (2007). Distribution, diversity and ecology of aerobic CO-oxidizing bacteria. Nat. Rev. Microbiol. 5, 107-118. doi: 10.1038/nrmicro 1595

Lang, S. Q., Butterfield, D. A., Schulte, M., Kelley, D. S., and Lilley, M. D. (2010). Elevated concentrations of formate, acetate and dissolved organic carbon found at the Lost City hydrothermal field. Geochim. Cosmochim. Acta 74, 941-952. doi: 10.1016/j.gca.2009.10.045

Mariotti, A., Germon, J. C., Hubert, P., Kaiser, P., Letolle, R., Tardieux, A., et al. (1981). Experimental determination of nitrogen kinetic isotope fractionation: some principles; illustration for the denitrification and nitrification processes. Plant Soil 62, 413-430. doi: 10.1007/BF02374138

Marques, J. M., Carreira, P. M., Carvalho, M. R., Matias, M. J., Goff, F. E., Basto, M. J., et al. (2008). Origins of high $\mathrm{pH}$ mineral waters from ultramafic rocks, Central Portugal. Appl. Geochem. 23, 3278-3289. doi: 10.1016/j.apgeochem.2008.06.029

McAuliffe, C. (1971). GC determination of solutes by multiple phase equilibration. Chem. Technol. 1, 46-51.

McMurdie, P. J., and Holmes, S. (2013). phyloseq: an R package for reproducible interactive analysis and graphics of microbiome census data. PLOS ONE 8:e61217. doi: 10.1371/journal.pone.0061217

Mills, C. T., and Goldhaber, M. B. (2010). On silica-based solid phase extraction techniques for isolating microbial membrane phospholipids: Ensuring quantitative recovery of phosphatidylcholine-derived fatty acids. Soil Biol. Biochem. 42, 1179-1182. doi: 10.1016/j.soilbio.2010.03.023

Morrill, P. L., Kuenen, J. G., Johnson, O. J., Suzuki, S., Rietze, A., Sessions, A. L., et al. (2013). Geochemistry and geobiology of a present-day serpentinization site in California: the Cedars. Geochim. Cosmochim. Acta 109, 222-240. doi: 10.1016/j.gca.2013.01.043
Nakagawa, F., Tsunogai, U., Gamo, T., and Yoshida, N. (2004). Stable isotopic compositions and fractionations of carbon monoxide at coastal and open ocean stations in the Pacific. J. Geophys. Res. 109, C06016. doi: 10.1029/2001JC0 01108

Neal, C., and Stanger, G. (1983). Hydrogen generation from mantle source rocks in Oman. Earth Planet. Sci. Lett. 66, 315-321. doi: 10.1016/0012-821X(83) 90144-9

Nelson, M. C., Morrison, H. G., Benjamino, J., Grim, S. L., and Graf, J. (2014). Analysis, optimization and verification of illumina-generated 16S rRNA gene amplicon surveys. PLoS ONE 9:e94249. doi: 10.1371/journal.pone.00 94249

Oremland, R. S., Miller, L. G., and Whiticar, M. J. (1987). Sources and flux of natural gases from Mono Lake, California. Geochim. Cosmochim. Acta 51, 2915-2929. doi: 10.1016/0016-7037(87)90367-X

Perner, M., Kuever, J., Seifert, R., Pape, T., Koschinsky, A., Schmidt, K., et al. (2007). The influence of ultramafic rocks on microbial communities at the Logatchev hydrothermal field, located $15^{\circ} \mathrm{N}$ on the Mid-Atlantic Ridge. FEMS Microbiol. Ecol. 61, 97-109. doi: 10.1111/j.1574-6941.2007.00325.x

Proskurowski, G., Lilley, M. D., Seewald, J. S., Früh-Green, G. L., Olson, E. J., Lupton, J. E., et al. (2008). Abiogenic hydrocarbon production at Lost City Hydrothermal Field. Science 319, 604-607. doi: 10.1126/science.1151194

Pruesse, E., Quast, C., Knittel, K., Fuchs, B. M., Ludwig, W., Peplies, J., et al. (2007). SILVA: a comprehensive online resource for quality checked and aligned ribosomal RNA sequence data compatible with ARB. Nucleic Acids Res. 35, 7188-7196. doi: $10.1093 / \mathrm{nar} / \mathrm{gkm} 864$

Rudd, J. W. M., Hamilton, R. D., and Campbell, N. E. R. (1974). Measurement of microbial oxidation of methane in lake water. Limnol. Oceanogr. 19, 519-524. doi: 10.4319/lo.1974.19.3.0519

Ruess, L., and Chamberlain, P. M. (2010). The fat that matters: soil food web analysis using fatty acids and their carbon stable isotope signature. Soil Biol. Biochem. 42 1898-1910. doi: 10.1016/j.soilbio.2010.07.020

Schloss, P. D., Westcott, S. L., Ryabin, T., Hall, J. R., Hartmann, M., Hollister, E. B., et al. (2009). Introducing mothur: open-source, platform-independent, community-supported software for describing and comparing microbial communities. Appl. Environ. Microbiol. 75, 7537-7541. doi: 10.1128/AEM.01 541-09

Schrenk, M. O., Brazelton, W. J., and Lang, S. Q. (2013). Serpentinization, carbon and deep life. Rev. Mineral. Geochem. 75, 575-606. doi: 10.2138/rmg.20 13.75 .18

Scott, K. M., Lu, X., Cavanaugh, C. M., and Liu, J. S. (2004). Optimal methods for estimating kinetic isotope effects from different forms of the Rayleigh distillation equation. Geochim. Cosmochim. Acta 68, 433-442. doi: 10.1016/S00167037(03)00459-9

Sleep, N. H., Bird, D. K., and Pope, E. C. (2011). Serpentinite and the dawn of life. Philos. Trans. R. Soc. B Biol. Sci. 366, 2857-2869. doi: 10.1098/rstb. 2011.0129

Sleep, N. H., Meibom, A., Fridriksson, T., Coleman, R. G., and Bird, D. K. (2004). H2-rich fluids from serpentinization: geochemical and biotic implications. Proc. Natl. Acad. Sci. U.S.A. 101, 12818-12823. doi: 10.1073/pnas.0405289101

Suhr, G. (1992). Upper mantle peridotites in the Bay of Islands Ophiolite, Newfoundland: formation during the final stages of a spreading centre? Tectonophysics 206, 31-53. doi: 10.1016/0040-1951(92)90366-E

Suhr, G., and Cawood, P. A. (1993). Structural history of ophiolite obduction, Bay of Islands, Newfoundland. Geol. Soc. Am. Bull. 105, 399-410.

Suzuki, S., Ishii, S., Wu, A., Cheung, A., Tenney, A., Wanger, A., et al. (2013). Microbial diversity in The Cedars, an ultrabasic, ultrareducing, and low salinity serpentinizing ecosystem. Proc. Natl. Acad. Sci. U.S.A. 110, 15336-15341. doi: $10.1073 /$ pnas. 1302426110

Suzuki, S., Kuenen, J. G., Schipper, K., Van Der Velde, S., Ishii, S., Wu, A., et al. (2014). Physiological and genomic features of highly alkaliphilic hydrogen-utilizing Betaproteobacteria from a continental serpentinizing site. Nat. Commun. 5:3900. doi: 10.1038/ncomms4900

Szponar, N. (2012). Carbon Cycling at a Site of Present-Day Serpentinization: The Tablelands, Gros Morne National Park. M.Sc. thesis - paper based, Memorial University.

Szponar, N., Brazelton, W. J., Schrenk, M. O., Bower, D. M., Steele, A., and Morrill, P. L. (2013). Geochemistry of a continental site of serpentinization in the Tablelands Ophiolite, Gros Morne National Park: a mars analogue. ICARUS 224, 286-296. doi: 10.1016/j.icarus.2012.07.004 
Tiago, I., and Verissimo, A. (2013). Microbial and fuctional diversity of a subterrestrial high $\mathrm{pH}$ groundwater associated to serpentinization. Environ. Microbiol. 15, 1687-1706. doi: 10.1111/1462-2920.12034

Tsunogai, U., Nakagawa, F., Komatsu, D. D., and Gamo, T. (2002). Stable carbon and oxygen isotopic analysis of atmospheric carbon monoxide using continuous-flow isotope ratio MS by isotope ratio monitoring of CO. Anal. Chem. 74, 5695-5700. doi: 10.1021/ac020290x

Willems, A., Busse, J., Goor, M., Pot, B., Falsen, E., Jantzen, E., et al. (1989). Hydrogenophaga, a new genus of hydrogen-oxidizing bacteria that includes Hydrogenophaga flava comb. nov., Hydrogenophaga palleronii, Hydrogenophaga pseudoflava and Hydrogenophaga taeniospiralis. Int. J. Syst. Bacteriol. 39, 319-333. doi: 10.1099/00207713-39-3-319

Zelles, L., Bai, Q. Y., Beck, T., Beese, F., Bar, Q. Y., and Becki, T. (1992). Signature fatty acids in phospholipids and lipopolysaccharides as indicators of microbial biomass and community structure in agricultural soils. Soil Biol. Biochem. 24, 317-323. doi: 10.1016/0038-0717(92)90191-Y

Ziegler, S. E., Billings, S. A., Lane, C. S., Li, J., and Fogel, M. L. (2013). Warming alters routing of labile and slower-turnover carbon through distinct microbial groups in boreal forest organic soils. Soil Biol. Biochem. 60, 23-32. doi: 10.1016/j.soilbio.2013.01.001
Conflict of Interest Statement: The authors declare that the research was conducted in the absence of any commercial or financial relationships that could be construed as a potential conflict of interest.

Received: 27 June 2014; accepted: 28 October 2014; published online: 13 November 2014.

Citation: Morrill PL, Brazelton WJ, Kohl L, Rietze A, Miles SM, Kavanagh H, Schrenk MO, Ziegler SE and Lang SQ (2014) Investigations of potential microbial methanogenic and carbon monoxide utilization pathways in ultra-basic reducing springs associated with present-day continental serpentinization: the Tablelands, NL, CAN. Front. Microbiol. 5:613. doi: 10.3389/fmicb.2014.00613

This article was submitted to Extreme Microbiology, a section of the journal Frontiers in Microbiology.

Copyright (c) 2014 Morrill, Brazelton, Kohl, Rietze, Miles, Kavanagh, Schrenk, Ziegler and Lang. This is an open-access article distributed under the terms of the Creative Commons Attribution License (CC BY). The use, distribution or reproduction in other forums is permitted, provided the original author(s) or licensor are credited and that the original publication in this journal is cited, in accordance with accepted academic practice. No use, distribution or reproduction is permitted which does not comply with these terms. 